\title{
Violence and hatred in Psalm 137: The psalm in its ancient social context $^{1}$
}

\author{
Y Steenkamp ${ }^{2}$ \\ (University of Pretoria)
}

ABSTRACT

\section{Violence and hatred in Psalm 137: The psalm in its ancient social context}

Psalm 137 has become notorious for the brutality and bloodthirstiness that characterise its last verses. In the face of many past criticisms which rejected the Old Testament as a book of violence, both Christians and Jews need to take texts such as Psalm 137 seriously and interpret them against the social and cultural customs of their time. Before Psalm 137 can be judged against the ethical norms of modern societies, the text must first be understood in its ancient context. The aim of this paper is to show that a better understanding of the socio-cultural background of the Psalm may enhance our understanding of vv. 7-9, as well as of the Psalm as a whole. The hypothesis is that the social values of honour and shame feature so prominently in the Psalm that they form a key to the interpretation of the poem.

\section{INTRODUCTION}

The hatred and violence that characterise the last three verses of Psalm 137 has been a stumbling block to Christian and non-Christian alike, and both groups meet the acute brutality and bloodthirstiness of these verses with scepticism. For the Christian, it seems impossible to harmonise these verses with the forgiveness preached by Jesus (Math 5:44), and so, at least in the Christian context, the problem is therefore also one of canon. In the face of many past criticisms which rejected the Old Testament as a book of violence, whose God is often described as a 'man of war' (Exod 15, Isa. 42), both Christians and Jews need to take texts such as Psalm 137 seriously and interpret them against the customs and social institutions of their time (Van Dyk 2003:96). Historical critical study is the key to the

1 This paper was submitted in completion of a research module for the Department of Ancient Languages, University of Pretoria.

2 Y Steenkamp is a post graduate student at the Department of Ancient Languages under supervision of Prof G T M Prinsloo. 
theological understanding of Biblical texts, and makes it possible for the texts to be interpreted and understood within their larger socio-historical, literary and also canonical contexts (Human 2003:263). The Old Testament may never be read in isolation from its ancient Near Eastern Umwelt (Human 2003:268). Secondly, Christians and Jews need also to judge such texts against the ethical norms of modern societies, especially since the Bible has been and still is often abused for the justification of violent acts (Van Dyk 2003:96). This last step, though very relevant to the field of Old Testament scholarship, falls beyond the scope of the present study. However, no such questions regarding the relevance and normativity of the text can be answered without first understanding the text in its ancient context, and so that is the issue addressed by this study. The aim of this paper is to show that a better understanding of the socio-cultural background of the Psalm may enhance our understanding of vv. 7-9, as well as of the Psalm as a whole. The hypothesis is that the social values of honour and shame feature so prominently in the Psalm that it forms a key to the interpretation of the poem (Botha 2001:392). After a short overview of the structure and contents of the Psalm will follow a discussion of ancient social values, which will then be applied to Psalm 137 in order to show how such an approach enlightens the reader in his or her understanding of the Psalm.

\section{SEGMENTATION AND TRANSLATION ${ }^{3}$}

$\begin{array}{ccc}\text { A } & 1 \mathrm{a} & 3 \\ \text { b } & 3 \\ \text { c } & 2\end{array}$

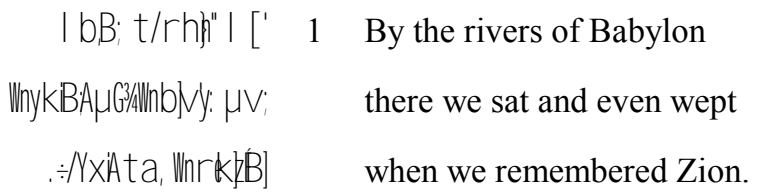

3 The criteria used for this segmentation are the masoretic punctuation marks which preserve an ancient tradition. Halle and McCarthy (1981:161-167) argues, however, that the approach that seems most productive of insights is syllable counting. Syllables following the last stress in a line are regarded as extra-metrical (confirmed by retraction of stress to reduce syllable count one by one). In their opinion (also supported by Watson (2001:105)), there can be little doubt that this proposal holds true for Psalm 137 (1981:161). Yet their proposal is not accepted here. Although the emendations they need to make to the text does not alter the meaning as such, and although these emendations are relatively few, the grounds on which they are made are debatable and lack the power to convince (cf. Halle \& McCarthy 1981:165-167). "The lack of objective criteria in the identification of syllables renders an algorithmic analysis hypothetical; the ancient singers and modern exegetes need the thematic divisions of the strophic structure for the interpretation of the psalm" (Terrien 2003:865). 


\begin{tabular}{|c|c|c|c|c|c|c|}
\hline & B & $2 a$ & 2 & 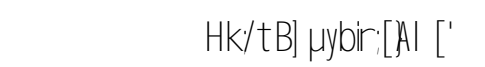 & 2 & Upon the poplar trees in its midst \\
\hline & & $\mathrm{b}$ & 2 & Whyt er Neei Wayl T; & & we hung our harps. \\
\hline & & $3 a$ & 5 & 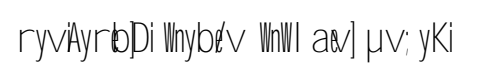 & 3 & There our captivators asked of us the words of a song \\
\hline & & $\mathrm{b}$ & 2 & hj mb i vayl e/t wò & & and our oppressors festivity, \\
\hline & & $\mathrm{c}$ & 4 & $\therefore$ IY i r w W mi Wal ; W yw i & & 'Sing for us of the songs of Zion!' \\
\hline & & $4 \mathrm{a}$ & 3 & h wh yêr w at a , r yw hi: ya e & 4 & How can we sing the song of YHWH \\
\hline & & $\mathrm{b}$ & 3 & . r k net md i 'l [ ' & & on foreign soil? \\
\hline II & $\mathrm{C}$ & $5 \mathrm{a}$ & 2 & 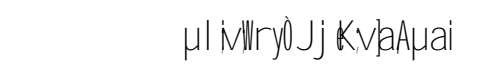 & 5 & If I forget you, oh Jerusalem, \\
\hline & & $\mathrm{b}$ & 2 & .yngmiojoj KV Ti & & let my right hand be lamed; \\
\hline & & $6 a$ & 4 & 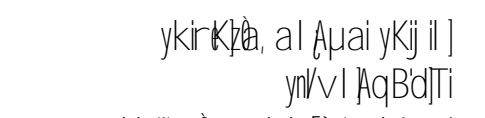 & 6 & $\begin{array}{l}\text { Let my tongue cleave to the roof of my mouth if I } \\
\text { don't remember you, }\end{array}$ \\
\hline & & $\mathrm{b}$ & 3 & 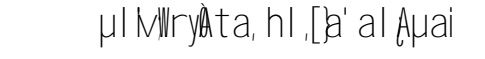 & & if I don't lift Jerusalem \\
\hline & & $\mathrm{c}$ & 3 & .yt j mb iv a r ol [' & & above my chief joy. \\
\hline III & $\mathrm{D}$ & $7 \mathrm{a}$ & 4 & 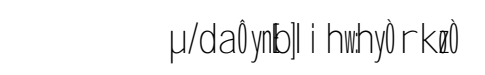 & 7 & Remember, oh YHWH, the Edomites, \\
\hline & & $\mathrm{b}$ & 3 & $\mu l$ i W you $/ y$ t a e & & the day of Jerusalem, \\
\hline & & $8 \mathrm{a}$ & 3 & $W[;$ Wr $[; \mu y r$ mata; & & they who said, 'plunder, plunder \\
\hline & & $\mathrm{b}$ & 3 & . $H B ; d / s y \hat{D}^{\prime} d\left[{ }^{\prime}\right.$ & & to its' very foundation!' \\
\hline & E & $9 \mathrm{a}$ & 2 & $h d V W V h^{\prime} \mid$ b BAt B' & 8 & Oh daughter of Babel, who will be destroyed; \\
\hline & & $\mathrm{b}$ & 2 & 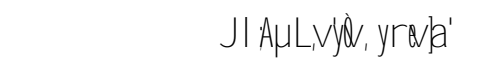 & & Happy is he who repays you \\
\hline & & $\mathrm{c}$ & 3 & 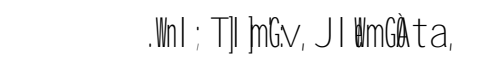 & & what you deserve, according to what you did to us! \\
\hline & & $\begin{array}{l}10 \\
\mathrm{a}\end{array}$ & 5 & 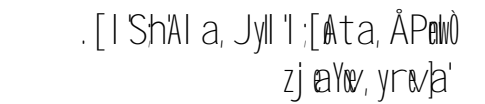 & 9 & $\begin{array}{l}\text { Happy is he who seizes and dashes your children } \\
\text { against the rock! }\end{array}$ \\
\hline
\end{tabular}

\section{THE STRUCTURE AND CONTENT OF PSALM 137}

\subsection{Stanza I}

Although the name Babel goes in front, as in the last strophe, the subject "we", the captives, dominate the first stanza. The name Zion comes at the end of strophe A and introduces the Stichwort r kz that, together with its antonym $j k v$ is to dominate the middle stanza. Strophe B is defined by the cohesion of suggestion (with assertive $y K i$ in front) and refusal (with rhetoric I ya $A$, and even more by the five-fold use of the hollow root $r \mathrm{~W}$, supported by alliteration of many more sibilants (Fokkelman 2000:301). Anderson's opinion (1972:898) that the hanging up of the harps could either imply that inanimate objects could express sorrow and mourning, as in Lamentations 1:4, or could be a metaphor for deep sorrow unrelieved by any joys, does not convince. The phrase is probably a mere reference to 
the fact that the captives refused to sing, and so hung up their harps. The direct speech of the captors may be a mocking request tinged with sarcasm (Anderson 1972:898). This will be dealt with extensively in a moment. The rhetorical question of line 4 does not imply that to sing the songs of YHWH would be unlawful in a foreign land, because the psalms continued to be sung throughout the exile. The r wi, however, had an end during the exile as far as it had to withdraw to the private family sphere and houses of prayer, so that the holy might not be profaned (Delitzsch 1973:334). It might also mean 'How can we who are unclean (in that we are punished) sing Yahweh's praises to an unclean people in an unclean land?' (Anderson 1972:899). Zion again completes a verse, adding to the emphasis already placed on the word in strophe A.

\subsection{Stanza II}

The despair of this stanza climaxes in a double intention to remember Jerusalem, which is couched in the language of the oath, in this case a selfcursing formula formulated in compound sentences and three times the conditional conjunction, patterned in a chiasm (Fokkelman 2000:301). He invokes on himself the penalty of physical handicap. May he never be able to play the lyre again or sing again, should he forget (Allen 1983:242) ${ }^{4}$ ! The poet arms himself against the temptation to apostasy and danger of denying God, a fear that was grounded during the period of the exile, for all those in whom the remembrance of Zion was lost gave themselves over to heathenism (Delitzsch 1973:334). The "I" of stanza II, as opposed to the first person plural of stanza I, may also be understood collectively. The speaker voices the commitment and loyalty of his whole community, and so unites them in himself 5 . The sound $-i$ unifies the stanza, as does the references to body parts which express the devotion to Jerusalem.

4 Zenger (1998b:110-111) understands this to be a physical act of laying the right hand on the throat that had to be carried out by the person making the vow. If the Psalmist forgets Jerusalem, the hand would "forget" and choke the person. It is more likely, though, in the context of the strong music theme, that it refers to the playing of a musical instrument and singing as such.

5 "Insofern die Psalmen Antwort sind, sind sie zumeist Texte, in denen ein Ich oder ein Wir redet. Manchmal verschmelzen Ich und Wir sogar in ein und demselben Psalm (z.B. Ps 40). Die Exegese hat oft diskutiert, ob das Ich ein individuelles oder kollektives Ich ist. Heute wissen wer, da $\beta$ dies eine eher moderne Unterscheidung ist. Auch wenn der einzelne Israelit Ich sagte, wußte er sich eingebunden - gerade im Angesicht seines Gottes, vor dem und zu dem er 


\subsection{Stanza III}

In this stanza the participants of stanza I largely reappear, although now their roles have now been reversed (Allen 1983:242). The imperative of the Stichwort $\mathrm{rkz}$ is a euphemistic request to YHWH that Edom be punished. All parts of the psalm, ("Erlebnisgedicht"), as also the wish for the punishment and the curse of stanza III, connects the motif of remembering and not forgetting. "Die durch die Betonung des Leitworts 'gedenken' unausgesprochene Frage nach Gottes Gedenken an den Zion kennzeichnet die Situation des Psalms als lähmend wirkende tiefe Depression, die den Schock der Katastrophe noch nicht reflektierend überwinden kann" (Seybold 1996:509). The direct speech of the Edomites with the double imperative "plunder, plunder"!, reflect the imperative of the Babylonian captors in strophe B, "sing to us!". The barbarous practice mentioned in v. 9 was a feature of ancient Near Eastern warfare. It effected total destruction by making war upon the next generation (Allen 1983: 137). The name Babel appears as it did in strophe $A$, and so the strophic structure can be recognized as an ABXB'A' pattern (Fokkelman 2000: $302)$.

"The order of emotions, which a poet may adopt as the lyrical order of textual units, differs from the chronology of events. The NewBabylonian campaign in Judaea and the destruction of city and temple have been followed by the Edomites' plunder of the land; the inhabitants have been deported to Mesopotamia, and when the victors asked the exiles to sing, they refused and hung their harps on the trees. In the lyrical order of Psalm 137 the case is exactly the reverse: people weep by the rivers of Babylon (strophe A, vv. 1-2) and refuse to sing (strophe B, vv. 3-4); Jerusalem is not forgotten (Lstrophe 3, vv. 5-6): Edom and Babylon are remembered in terms of burning vindictiveness (strophes $\mathrm{D}$ and $\mathrm{E},=\mathrm{vv} .7$ and 8-9). This lyric anti-chronology is then filled out and marked off by means of various poetic devices" (Fokkelman 2000:301). Allen (1983:240) points out the concentric pattern of the psalm as described by

betete - in das Wir des Gottesvolks. Und umgekehrt wußte sich Israel vor dem Du seines Gottes als eine Gemeinschaft, deren Leben unteilbar und verletzlich zugleich war wie das eines Ich. Darüberhinaus zeigt der Vergleich der Psalmen Israels mit denen seiner Umwelt: Die Wir-Gebete sind ein Spezifikum Israels" (Zenger 1998a:324). 
Freedman: On the outside, the repeated I [ ' followed by a noun and the preposition $B$ ] in $1 \mathrm{abc} / 2 \mathrm{ab}$ are mirrored in the repeated $\mathrm{V}$, yr $\mathrm{A}$ ' of $9 \mathrm{abc} / 10$. Babel completes this inclusio. Near the edge of the psalm $3 a b c$ and strophe D match in featuring quotation of enemies with plural imperatives. Deeper into the psalm lie the two lines $4 \mathrm{ab}$ and $6 \mathrm{bc}$, each made up of conjunction and verb, object indicator and object, and I [' with a genitival phrase. At the heart of the composition cluster is lines $5 \mathrm{ab}-6 \mathrm{a}$, with their precise chiastic order. Allen notes, however, that there are some key terms in the psalm which do not feature in the analysis, and that while Freedman is right in highlighting the similarities between lines $4 \mathrm{ab}$ and $6 \mathrm{bc}$, their parallelism may be due to a reason quite different from concentricity. Nevertheless, the central core of the psalm (stanza II) provides the key to the meaning of the whole psalm, the memory of Zion (Terrien 2003:865). There is, however, progression towards the end of the psalm, where the psalm reaches its climax in the last strophe, which also possesses the most complicated syntactic compositions of the whole psalm.

\section{GATTUNG AND SITZ IM LEBEN}

\subsection{Gattung}

The psalm does not easily fit into any of the common psalm-types. "Psalm 137 is an impressive example of the fact that in the history of psalm writing forms and categories have great staying power but are not the dominating factors. Setting and themes win through" (Kraus 1989:501). A vast variety of suggestions have been made as to the Gattung of Psalm $137^{6}$, but Prinsloo (2000:285-286) makes a good case for a Mischform. His hypothesis regarding the Gattung is outlined here shortly.

6 If the emphasis is to fall on the first stanza, the psalm could very well be classified as a communal lament, and if on the last stanza, as a Psalm of cursing. Be the second stanza the main theme, however, the psalm would resemble a song of Zion (Anderson 1972:897). Anderson (1972:897) then resorts to classify the psalm as a Communal Lament culminating in an imprecation upon enemies.

Fohrer (1968:292) classified it as a "noncultic song expressing personal emotions". Deissler (1965:184): "Ps 137 läßt sich schwer in eine Gattung einordnen. Dem Grundtenor nach gehört er zu den Sionsliedern, weist aber neben nur vereinzelten hymnischen Motiven (5-6) starke Anklänge an das Volksklagelied auf. Als Ganzes kann der Psalm indes nicht zum Klageliedrepertoire der Verbannten gehört haven. 
Stanza I reveals the characteristics of a Volksklage or Collective Lament ${ }^{7}$, while stanza II reveals the formal characteristics of a Song of Zion $^{8}$. Its content, however, does not correspond with a Song of Zion at all, but much rather with an individual lament where self imprecation plays a major role. The song of Zion is thus used here for the exact opposite purpose, so establishing paradoxal irony. This is further emphasized by the fact that the communal lament of stanza I has now become an individual lament, and also by the light $-i$ sounds which usually belong to light, lyrical literature. Prinsloo then finally describes stanza II as an ironic hymn characterized by bitterness and the imprecation of the self. In stanza III another Gattung is manipulated. It opens with $r \mathrm{kz}$, a formula which normally recalls the great deeds of YHWH. The yr $\mathrm{e}$ formula also appears twice in this stanza, which is usually found in a Gratulationstext, and also very often part of the Songs of Zion. However, the content of stanza III again does not correspond with these Gattungen. $r k z$ does not recall the deeds of YHWH, but calls on him to punish the enemies of Israel. Like-wise the yr $\mathbb{E}$ a'-formulas convey no blessing, but rather a terrible curse. By using the Gattung in the opposite way than usual, irony is created and the bitterness of the curse emphasized. Prinsloo then describes stanza III as a curse text. He concludes: Psalm 137 is a Mischgattung wherein three different Gattungen are used in a functional

Denn der Anfang blickt bereits auf die Gefangenschaft zurück (vgl. Dort in v. 2 und 3), und der Schlu $\beta$ ist - zumindesten für den Vortrag in einem weiteren Kreis in Babylon undenkbar. Darum kommt als Sitz im Leben am ehesten eine Sionsklagefeier auf den Stummern des noch darniederliegenden Tempels in Betracht (Wiederaufbau 520-515 v. Chr.). Doch wäre auch gut ein spätere Zeitpunkt denkbar. Der Aufbau der Stadt lag bis Nehemias (um 450) im argen. Allerdings mu $\beta$ die Gefangenschaft noch für viele eine lebendige erinnerung gewesen sein. Der Psalmschlu $\beta$ pa $\beta$ t auch noch in diese spätere Situation. Denn Kyrus hat die Stadt Babel bei der Einnahme (538 v. Chr.) geschont. Erst Xerxes fügte ihr schwere Zerstörungen zu (478 v. Chr). Basis des gegenwärtigen Psalms könnte eine Klagelied aus dem Exil selbst gewesen sein".

7 Complaint about the situation, first person plural, particle I yae (Prinsloo 2000:285)

8 Jerusalem/Zion stands in a central position as well as in a vocative, the greatness of Zion is exclaimed. The verb ל is often used for grateful remembrance of the deeds of YHWH (Prinsloo 2000:285). 
manner, emphasizing the progression that takes place in the Psalm. The psalm moves from a Lament to a Self Imprecation and ends in a Curse 9 .

\subsection{Sitz im Leben}

Kraus ${ }^{10}$ maintains that Psalm 137 is the only Psalm in the Psalter that can be dated reliably, because of the reference to the Israelites in exile, and because the Babylonian Empire still exists (1989:501). This he bases, however, on his changing of the passive participle $h d W V V^{\prime} h^{\prime}$ "you who are destroyed" to an active $h d / d V h '$ "destroyer", a change not supported by any textual variants. The dating of the Psalm is, on the contrary, no easy task, and the text itself gives no clear indication. Yet the text has not left the reader completely without guidelines. The perfect verbs with which the psalm starts give the impression that the author is historically removed from the events described (Ogden 1982:89). The $\mu v$; is important - the land is distant and strange - not the place where the author finds himself at the time of writing (Delitzsch 1973:335). The use of the imperfect in the rhetorical question of line $4 \mathrm{ab}$ denotes the attitude of those who, having reached Jerusalem, now pour out their hearts in grief at what they have endured (Ogden 1998:90). There is also a logical difference between stanza I and the remainder of the poem. While in vv. 3-4 the psalmist refuses to sing a song of Zion, in v. 6 he sets under a curse any failure to sing and play in Jerusalem's honour (Allen 1983:239). While vv. 1-4 lie in the past for the psalmist, the self imprecation of stanza I is formulated to apply to any period in time (Deissler 1965:185) and in 5a he can address Jerusalem directly, as though present there. The early years of return from exile, either before the rebuilding of the temple (537-516/5 BCE) or of the city walls (537-445 BCE) seem to be the most likely period of composition. (Allen 1983:239; Anderson 1972:897). The author need not ever have been in the exile himself, but the passionate sentiment of the

9 "Whereas Gunkel was fully aware of psalms of mixed forms, he tended to regard such phenomena in a negative light as a part of a process of deterioration. Increasingly the modern approach has moved in the opposite direction in seeing the change, growth, and loosening of the traditional conventions in a positive theological light as the best key to the new kerygmatic function to which each psalm has been assigned" (Childs 1992:193).

10 Also Seybold (1996:509), although he maintains the possibility that it may have been written after the return from the exile. 
poem may have sprung from personal experience ${ }^{11}$. The $v_{0}$ which is repeated three times in v. 8, corresponds to the time of the composition of the Psalm which is required by its contents, just as is the case with the paragogic $i$ in the future in verse 6 . In other respects the language is classic (Delitzsch 1973:332).

Kraus supposed that the psalm is best explained from a situation of cultic lamentation, that the psalm suggests a gathering of the exiles for prayer and lamentation, and that vv. 1 and 2 are not lyrical impressions but a specific act of the common rite of lamentation (Kraus 1989:502). It is not imperative, though, to assume that the author was speaking of religious gatherings of the captives and that vv. 1-2 refer to cultic activities. The psalm probably had a cultic setting, in view of its content. The role of the psalm in the Psalter, closing the supplement to the Songs of Ascents may indicate that it was used as a processional song (Allen 1983:239). It seems that the psalm was the product of the post exilic temple cult, and so it is a post exilic interpretation of the Exile and also of the fall of Babylon, implicating YHWH as the instigator behind the fall of the Babylonian Empire.

\subsection{Psalm 137 in Book V of the Psalter}

In the compositional context Psalm 137 is to be read as a theological commentary on the Zion Psalms (Pss 120-136). Psalm 137 serves - like Psalm 107 - to introduce the David collection of Psalms $138-145^{12}$. In that context, Psalm 138 becomes the direct answer to the question of Psalm 137: "How shall we sing the song of YHWH?" (Miller 1998:105).

11 Anderson (1972:897) maintains that he must have been exiled after the fall of Jerusalem, and that he may have been one of the Temple musicians taken to Babylon as an entertainer. While the psalm was written, though, he notes that its author was no longer in Babylon, but that he must have belonged to the generation which had seen the destruction of the Holy City, therefore the date could hardly be later than the rebuilding of the Temple in $515 \mathrm{BCE}$, and not earlier than $537 \mathrm{BCE}$.

12 "If one considers this purposeful juxtaposition of 137 and 138 as the beginning of the collection of Davidic psalms, then the twice emphasized deliverance of the royal David (=Israel) from the power of the שוֹ in 144.7 and 11 , as well as the "new song" announced in 144.9, acquire a special contextual significance: Psalm 144 is then envisioning that (eschatological) time when Israel's life "in a strange land" comes to an end and Israel can finally sing the new songs about the universal kingdom of the God of Zion - together with "all flesh" which Ps. 145.21 strives to achieve" (Zenger 1998c:96). 
Furthermore, the location of the psalm immediately after two psalms which celebrate YHWH's gift of the land to the covenant nation, conveys the reversal expressed by the rhetorical question (4ab) even more poignantly (Allen 1983:241).

\section{PSALM 137 IN ITS SOCIAL CONTEXT}

\subsection{Ancient social values}

The most important dramatis personae in Psalm 137 are the exiled community, Babylon, YHWH and the Edomites. Even though the name YHWH occurs only twice $(4 \mathrm{a}, 7 \mathrm{a}), \mathrm{He}$ is implied in the first and second stanzas with the references to Zion and Jerusalem. To the speaker, Jerusalem is no less than the seat of the visible rule of YHWH on earth, supporting the visible earthly order (Bright 1975:237). The relationships between these groups are defined predominantly in terms of the social values of honour and shame (Botha 2001:393). Honour and shame are core values of the ancient Mediterranean world, which communicate relative social status. Honour is a socially and publicly acknowledged claim to worth, whereas shame, the opposite of honour, is created when such a claim is publicly denied (Malina 1998:54-55). While honour is the highest value, public humiliation due to the loss of honour is a fate worse than death (Plevnik 1998:108). Honour is primarily a group value, and is embodied by adult males, who must achieve honour in public contests (Plevnik 1998:107). "Honour is associated with a value cluster that includes: strength, courage, daring, valour, generosity, and wisdom. Weakness, cowardice, and lack of generosity indicate lack of honour, and hence, are despised" (Plevnik 1998:107). Because honour and shame are perceived as limited goods, one cannot gain it without shaming someone else. This results in the competitive nature of the quest for honour. In this regard the value cluster "Authoritarianism" becomes relevant, which is rooted in the social experience of authority nearly always sanctioned by force (Malina 1998:12). The whole ancient Mediterranean world was a world of authoritarianism, and in such communities violence always have a huge part to play. The honour of a group is essentially bound to the honour of its leader, just as the honour of a nation is essentially bound the honour of their god. One value of this cluster of Authoritarianism is 'Domination orientation', a value that imposes sanctions of power in order to gain honour (Pilch 1998:49). This value is realized by the subjection of others. "Lording it over" others and "being subject to" others in the 
Mediterranean world are means by which honour is gained and shame is imposed (Pilch 1998:49). The values described above shape the meaning of Psalm 137. What follows, is a discussion of the Psalm in light of these values.

\subsection{Stanza I}

Strophe A describes the deep sorrow of the exiled community in the foreign land of Babylon. They cry at the remembrance of Zion, and more specifically, they cry in a foreign land. Land was an extremely important possession in these ancient Near Eastern cultures. The land where the people of the tradition dwell in families provided the framework in which honour, shame and tradition could function (McVann 1998:77). According to the Deuteronomistic literature, the land was also a gift from YHWH, and therefore sacred (Dt 5:28-33). Furthermore, other lands and the peoples who live in them were regarded as unclean (Lev 25:24-25; Dt 20:15-18; McVann 1998:77). Defending the nation's borders was not simply a matter of survival, but was a question of honour, shame and tradition as well (McVann 1998:77). Expulsion from the land was a catastrophe because of the resulting destruction of tradition and families. Being conquered by the Babylonians and carried away into a foreign land resulted in a considerable loss of honour for the people of Israel, which also reflected on YHWH, as He appeared unable to save them from the hand of this foreign nation and their foreign gods. Strophe A describes their situation. They are utterly shamed and hopeless, mourning the memory of Zion, the visible throne of YHWH over the world.

Strophe B further points out their hopeless situation. They hang up their harps as a symbolic action that they could not comply with the request of their captivators, who ask of them a song of Zion with the purpose of further shaming them and their God. The contrast between the contents of the songs of Zion and the present situation of the exiles should become apparent - that is the meaning of the demand that is heard in $3 \mathrm{c}$ (Kraus 1981:503). Zenger (1998:110) puts it well: "Ihre babylonische Verschleppung und die Zerstörung Jerusalems ('der Tag Jerusalems': vgl. V.7) ist in den Augen der Babylonier der klare Gegenbeweis gegen das in diesen Liedern besungene innige Verhältnis JHWHs zu Zion. In dieser Situation 'Zionslieder' zu singen, wäre glatter Hohn". The captors request hj mb i which Lenowitz (1987:149-159) has confirmed to be a mock-song of joy that lies at the centre of Ps 137. According to his understanding of the 
function of the psalmist (that of the mocking word in politics) in the national cult, the Psalmist would betray that function in singing a Jerusalem victory song in defeat, a song of Jerusalem outside of Jerusalem (1987:155).

\subsection{Stanza II}

Israel, as the chosen people of God, had her claim to honour based on her special relationship with YHWH, the evidence that God is on the side of Israel. This claim, however, depends on evidence of YHWH's continued interest in Israel. A calamity such as that described in the first stanza, points in the opposite direction and allows her enemies to mock and scorn her in denial of YHWH's concern. National defeat proves YHWH's abandonment of his people, which results in shame for Israel. The victors may also mock YHWH as God of Israel himself, who appears to them powerless to save Israel (Plevnik 1998:108). In order to set this right, Israel must demonstrate the opposite. She must insist on her righteousness, confess her guilt before YHWH, and appeal for help to YHWH's steadfast love $^{13}$. Likewise, for YHWH to punish the enemies of Israel would be evidence of honour due to the special relationship with God (Plevnik 1998:108-109). It is in this light that Stanza II should be understood. The speaker vows absolute loyalty to Jerusalem, which is for him the symbol of YHWH's history and relationship with Israel, to the point where he curses himself if he does not stay true to his vow. This is done in order to restore the broken relationship between YHWH and the nation. Second Isaiah announces a reversal of the situation of exile, resulting in the honour of Israel being restored (Is 54:4; 61:7; Plevnik 1998:109-110).

\subsection{Stanza III}

Strophe D deals with the Edomites, the first of Israels enemies to be named. The antagonism of Edom toward Israel, and vice versa, had begun in patriarchal times with the story of Jacob and Esau. Nebuchadnezzar employed Edomite mercenaries who encouraged the total annihilation of Israel's holy place (Ezek 25:12-14) (Terrien 2003:867). The curse on

13 In this regard it becomes very interesting indeed that Psalm 137 follows Psalm 136 in the Psalter, which is the celebration of YHWH's steadfast love (כתק) par excellance. 
Edom $^{14}$ plays an important role also in Lamentations 4:21 (Kraus 1981:503). It is interestingly inserted here, somewhat out of context. "Obviously the revenge against treacherous Edom was a special theme of the lamentations over the fall of Jerusalem" (Kraus 1981:503). Here, the poet lays claim to the unswerving loyalty to YHWH which he had expressed in Stanza II. "It is on the basis of this faithfulness to YHWH that the psalmist then makes his Petition that the destruction of Jerusalem be avenged" (Ogden 1982:90). The poet skillfully uses the same Leitwort r k Z, whereby he vowed his faithfulness in Stanza II. The poet confessed his own abiding remembrance of Jerusalem, and now he appeals to YHWH to do the same. So doing, the Edomites will be shamed by YHWH's punishment, and the honour of Israel and YHWH restored.

The last strophe is the most violent one in the psalm, and also forms the climax of the poem. Babylon had shamed the Israelites and their God when they destroyed Jerusalem and its temple, and took the people into exile. In Stanza I, the poet also described how the Babylonians further attempted to shame the Israelites by letting them sing the victory songs of Zion in defeat. Now the poet ends his poem with a reference to Babylon, just as he had started ${ }^{15}$. This time, however, the roles are reversed. Babylon is to be on the receiving end of destruction and violence. The author longs for the application of the lex talionis, the legal principle of "eye for eye, tooth for tooth" (cf. Exod 21:24; Anderson 1972:900). The scales must be balanced. Only when the Babylonians are destroyed and humiliated as the Israelites were, will the honour of both YHWH and

14 The Edomites remained one of the most dangerous adversaries of Israel after the return from exile. The book of Obadiah is a clear example of the animosity that existed between these two peoples and the judgement that Israel wished against the Edomites. See also Ezek 25:12, 35:14; Mal 1:2-3; Lam 4:21.

15 Gerstenberger (2001:393) reports Hartberger's comparison of Psalm 137 with Jeremiah 51, a long diatribe against Babylon: "Vocabulary and outlook do surprisingly correspond. Babylon is directly addressed and threatened, e.g., Jer. 51:13-14, 20-23. The last-mentioned four verses, furthermore, dwell on the verb "smash" (nps, Piel: 9 occurrences, plus participle/noun = "smasher" = "hammer", Jer 51:20a; note the wordplay. This verb occurs a total of only 21 times in the OT. Cf. the only other occurrence in the Psalter: Ps 2:9). Military and civilian people are "smashed" in Jer 51:20-23, although not "babes" as in Ps 137:9. There is some talk about "rocks", too, in Jer 51:25-26, supposedly the foundation of the city of Babylon (which does not fit geographically, but seems to be a standard concept for high-ranking, powerful cities)". 
Israel be restored" ${ }^{16}$ "Um die öffentliche Wiederherstellung der Weltordnung geht es in V.8-9. Wenn heute völkerrechtliche Sanktionen gegen Aggressoren und Staatsterroristen gefordert und durchgesetzt werden, hat dies ebensowenig mit 'Rache' zu tun wie der Schrei von V.8-9 nach einer Macht, die Babylon in die Schranken weist" (Zenger $1998^{\mathrm{b}}: 112$ ). The humiliation of Babylon must be public and violent, as had been the case with Israel when Jerusalem was destroyed. Public exposure is a typically female punishment, which explains why the poet addresses the enemy as the "daughter of Babylon". In the ancient Mediterranean, cities were considered female entities (Plevnik 1998:109). V. 9 describes war in the normal terminology of the time (cf $2 \mathrm{Kgs} 8: 12$; Is 13:16; Hos 10:14, 14:1 and Nah 3:10; Prinsloo 2000:291). The murder of children was often a military policy which had the purpose of annihilating an entire nation (Maré 2001: 345). Keel further mentions how neighboring peoples were subject to princes who were mere babes in the laps of their wet nurses. These infants manifested and represented the continuance of the power of their dynasty. Their death meant the end of despotism, and this may also resound in the poets strong request for violence (Keel 1978) ${ }^{17}$. The "undisguised vindictiveness" of the open request for retribution of strophe E remain at the level of advanced rhetoric by clothing the request in a double yr (Fokkelman 2000:302). Borrowing the beatitude form from the Song of Zion, the psalmist uses it ironically in commendation of

16 "The reason why the psalmist calls down God's punishment on the enemy is in order to show with whom the final decision rests, whether with men who blaspheme in their arrogant mockery or with God who is not mocked. For his own sake Yahweh cannot tolerate infringement of his own majesty by the enemy's mockery. This is the ultimate concern of the Psalmist which we must not fail to see, even though it is obscured and suppressed by his subsequent words of blind hate and vulgar rage" (Weiser 1962:796).

"The petition for revenge is a petition that appeals to Yahweh's power to control history". (Kraus 1989:504).

17 "Ps 137 ist ein politischer Psalm: Es geht um das ende der Terrorherrschaft Babylons. Das ist auch hinsichtlich des Bildes von den Kindern der Tochter Babel, die am Felsgestein des Straßenpflasters der Hauptsadt Babel zerschmettert werden sollen, bedeutsam. "Die Kinder" sind die Kinder des Königshauses, d. h. der Dynastie (vgl. Jes 7,14-16; 9:1-6). Das grausame Bild meint: Diese Dynastie des Terrors soll vollends ("mit Stumpf und Stiel") ausgerottet werden. Zur Frage einer alternativen Übersetzung von Ps 137,9 werden wir im letzten Kapitel einige Überlegungen anstellen (vgl. V) (Zenger 1998b:113). 
dire reprisal (Allen 1983:242). According to Lenowitz (1987:156), the psalmist responds here with the three hard stressed imperatives, with what the victors have requested: the $h j \mathrm{ml}$-song of $9 \mathrm{bc} / 10$, introduced to the now-defeated Babylonians/Edomites.

\section{CONCLUSION}

When Psalm 137 is read against the background of the social values of the ancient Mediterranean World, it becomes clear that understanding it as a mere expression of sorrow due to defeat and hatred towards those who caused the sorrow, is to misjudge the full meaning of the text. The psalm is an appeal to YHWH to restore the honour of his people by defeating her enemies, especially the two that were most involved on the day of Jerusalem's greatest shame in 586 BCE. A better understanding of the socio-cultural background of the Psalm enhances our understanding of vv. 7-9, as well as of the Psalm as a whole. The social values of honour and shame feature so prominently in the Psalm that it forms a key to the interpretation of the poem (Botha 2001:392). This paper has shown that an interpretative approach needs to take cognisance of the role of ancient social values in the cultural and religious world of post-exilic Israel (Botha 2001:400).

\section{Consulted literature}

Allen, L C 1983. Psalms 101-150. Dallas, Texas: Word Books Publisher (Word Biblical Commentary 21).

Anderson, A A 1972. The Book of Psalms Vol. 2 Psalms 73-150. London: Oliphants.

Botha, P J 2001. Honour and shame as keys to the interpretation of Malachi. Old Testament Essays 14, 392-403.

Bright, J 1975. The Authority of the Old Testament. Grand Rapids Michigan: Baker Book House.

Childs, B S 1992. Biblical Theology of the Old and New Testaments. Theological Reflection on the Christian Bible. Minneapolis: Fortress Press.

Deissler, A 1965. Die Psalmen III. Teil (Ps 90-150). Düsseldorf: Patmos-Verlag.

Delitzsch, F 1973. Psalms. Grand Rapids: Eerdmans (Commentary on the Old Testament).

Fokkelman, D F 2000. Major poems of the Hebrew Bible at the Interface of Prosody and Structural Analysis. Assen: Van Gorcum.

Fohrer, G 1968. Introduction to the Old Testament. London: SPCK. 
Follis, E R 1987. Directions in Biblical Hebrew Poetry. Sheffield, England: Sheffield Academic Press (JSOTSS 40).

Gerstenberger, E S 2001. Psalms part 2 and Lamentations. Grand Rapids Michigan: William B. Eerdmans (The Forms of the Old Testament Literature Vol. XV).

Halle, M \& McCarthy, J J 1981. The metrical structure of Psalm 137. Journal of Biblical Literature 100, 161-167.

Human, D J 2003. Teologie kroniek: Skrifverstaan en die Nuwe Hervorming. Verbum et Ecclesia 24, 260-276.

Keel, O 1978. The Symbolism of the biblical world. Ancient Near Eastern Iconography and the Book of Psalms. London: SPCK.

Kraus, H J 1989. Psalms 60-150 - A commentary. Minneapolis: Augsburg.

Lenowitz, H 1987. The mock-śimhâ of Psalm 137, in Follis 1987, 149-159.

Malina, B J 1998. Authoritarianism, in Pilch \& Malina 1998, 12-19.

Maré, L P 2001. Psalm 137: 'n (On)Christelike Psalm? Verbum et Ecclesia 22, 341351.

McVann, M 1998. Family-Centeredness, in Pilch \& Malina 1998, 75-79.

Miller, P D 1998. The end of the Psalter: A response to Erich Zenger. Journal for the study of the Old Testament 80, 103-110.

Ogden, G S 1982. Prophetic oracles against foreign nations and psalms of communal lament: The relationship of Psalm 137 to Jeremiah 49:7-22 and Obadiah. Journal for the study of the Old Testament 24, 89-97.

Pilch, J J 1998. Domination Orientation, in Pilch \& Malina 1998, 48-50.

Pilch, J J \& Malina, B J 1998. Handbook of Biblical social values. Peabody: Hendrickson.

Plevnik, J 1998. Honor/Shame, in Pilch \& Malina 1998, 106-115.

Prinsloo, W S 2000. Psalm 137: Ecclesia Pressa, Ecclesia Triumphans, in Prinsloo 2000, 281-293.

-, 2000. Die lof van my God solank ek lewe. Irene: Medpharm Publikasies (Edms) Bpk.

Seybold, K 1996. Die Psalmen. Tübingen: J.C.B. Mohr (Paul Siebeck) (Handbuch zum Alten Testament).

Terrien, S 2003. The Psalms - Strophic structure and theological commentary. Grand Rapids, Michigan: William B. Eerdmans Publishing Company.

Van Dyk, P 2003. Violence and the Old Testament. Old Testament Essays 16, 96-112. 
Watson, W G E 2001. Classical Hebrew Poetry. A Guide to its techniques. Sheffield, England: Sheffield Academic Press (Journal for the study of the Old Testament Supplement Series 26).

Weiser, A 1962. The Psalms. London: SCM Press Ltd (Old Testament Library).

Zenger, E 1998a. Das Buch der Psalmen, in E Zenger et al (Hrsg) ${ }^{3} 1998$. Einleitung in das Alte Testament. Stuttgart: Kohlhammer, 309-326 (Studienbücher Theologie $1,1)$.

-, 1998b. Ein Gott der Rache? Feindpsalmen verstehen. Freiburg: Herder.

-, 1998c. The Composition and Theology of the Fifth Book of Psalms, Psalms 107145. Journal for the study of the Old Testament 80, 77-101. 